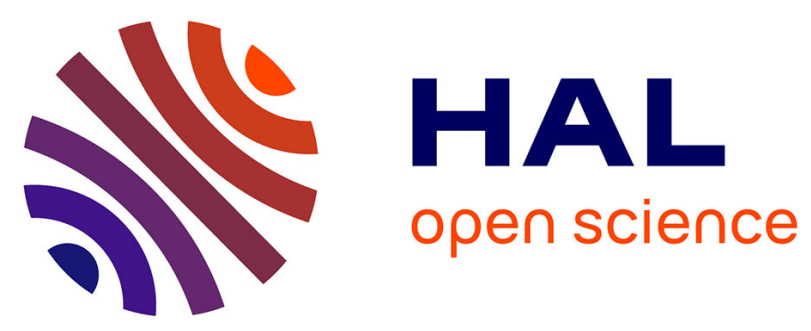

\title{
The representation of nuclear power in cinema: The contribution of a filmic analysis to understanding the public debate
}

\author{
Aurélien Portelli, Christophe Martin, Franck Guarnieri
}

\section{- To cite this version:}

Aurélien Portelli, Christophe Martin, Franck Guarnieri. The representation of nuclear power in cinema: The contribution of a filmic analysis to understanding the public debate. 24th European Safety and Reliability Conference - ESREL 2014, Sep 2014, Wroclaw, Poland. pp.1993-2000 - ISBN 9781138026810. hal-01063688

HAL Id: hal-01063688

https://hal-mines-paristech.archives-ouvertes.fr/hal-01063688

Submitted on 24 Sep 2014

HAL is a multi-disciplinary open access archive for the deposit and dissemination of scientific research documents, whether they are published or not. The documents may come from teaching and research institutions in France or abroad, or from public or private research centers.
L'archive ouverte pluridisciplinaire HAL, est destinée au dépôt et à la diffusion de documents scientifiques de niveau recherche, publiés ou non, émanant des établissements d'enseignement et de recherche français ou étrangers, des laboratoires publics ou privés. 


\title{
The representation of nuclear power in cinema: the contribution of a filmic analysis to understanding the public debate
}

\author{
A. Portelli \& C. Martin \\ CRC - MINES-ParisTech, Sophia Antipolis, France \\ ESAIP, Grasse, France \\ F. Guarnieri \\ CRC - MINES-ParisTech, Sophia Antipolis, France
}

ABSTRACT: Representations of the nuclear industry in European countries play a determining role in the public debate and the development of energy policies. Cinematic fiction as a media object contributes to our understanding of social reality and also exercises a major influence on public opinion, because of its ability to "colonize" awareness. The risk of nuclear conflict and the effects of radiation have inspired many filmmakers. However, there are far fewer films dedicated to the civilian use of nuclear power. Nevertheless, some notable works make it possible to investigate the topic through a focus on the relationship of man to their work in the sector, in particular the challenges of subcontracting maintenance activities, which is represented in terms of modern slavery.

The first part of this article outlines the methodology used to analyse how civilian nuclear power is represented in film. The second part puts the methodology into perspective and shows how workers in the sector are represented in a French film. Finally, the third part shows how this representation fits into the nuclear debate in France.

\section{INTRODUCTION}

Social representations encompasses concepts, beliefs, myths, objects or classes of individuals that appear as "shared cognitive schema that are developed by a group that allow its members to think, to represent the surrounding world and to orient and organise behaviour, often by prescribing or forbidding certain objects or practices" (Mannoni, 1998: 4.) Not only can they represent a serious challenge, they can also be at the centre of controversy, such as that concerning nuclear technology (Martin et al., 2013). The representations that feed the public debate on nuclear power can thus have a significant impact on the development of energy policy. They can be examined through a wide variety of sources, such as photography, novels, newspaper articles and cartoons, advertising, televised debates, documentaries or cinematic fiction.

The theme of the radioactivity was initially addressed by filmmakers a few years before the Second World War. Many films were made, inspired by the destruction of Hiroshima and Nagasaki, and the subsequent tensions between the two superpowers during the Cold War. These films reflected the anxieties of the population, such as the risk of nuclear war, the destruction of humanity or mutations due to radiation. Representations of the nuclear apocalypse, which have been studied by researchers for many years (Puiseux, 1987) have fuelled the imagination of audiences and influenced their perception of nuclear technology.

However, there are far fewer films dedicated to civilian use of nuclear power. Nevertheless, a few works stand out, such as The China Syndrome (Bridges, 1979), the short film Mont Fuji in Red taken from Dreams (Kurosawa, 1990), Land of Oblivion (Boganim, 2012), The Land of Hope (Zion, 2012) and Grand Central (Zlotowski, 2013); the latter was shown at the Cannes Film Festival in 2013 in the Un Certain Regard category. This French film evokes, in the context of a romance, the relationship between a man and his work in the nuclear power industry; it specifically addresses the challenges of subcontracting, which is represented in terms of modern-day slavery (Fig. 1). Subcontractors intervene during scheduled power outages in order to undertake maintenance operations that are not carried out by the operator's employees.

The aim of our research is therefore to show how the film illustrates the power relationships that

Gary, the main character in Grand Central, has not completed his training as a boilermaker and has held down a series of temporary jobs, before becoming a subcontractor in the nuclear sector. The work is demanding and dangerous. The protagonist is integrated into a team of workers and has a secret relationship with Karole, the partner of his colleague Toni. He is slowly contaminated, by both love and radiation.

Figure 1: Summary of Grand Central

feed the debate on the nuclear industry and its extremely widespread practice of subcontracting in 
the sector. The first part of the article presents the methodology used to analyse the representations of nuclear power in film. The second part puts the methodology into perspective and shows how the sector is represented in the film Grand Central. Finally, the third part illustrates how this representation fits into the public debate on nuclear energy in France.

\section{ANALYSIS OF CINEMATIC REPRESENTATIONS}

The issue of cinematic representations lies at the crossroads of filmic analysis and the social sciences. Our methodology is therefore the result of a (delicate) compromise between two disciplines that do not share the same background. Consequently, we must define the status of the filmic object. In the next step we demonstrate the relevance of the monographic approach to the study of the representation of civilian nuclear power, and we present our methodological framework.

\subsection{The status of the filmic object}

The question we seek to answer implies that the film is seen as a vector of representations that reflect the social reality which it forms part of. The researcher must therefore examine how the film restructures society in the form of entertainment, where the symbolism refers to the time it was made (Vanoye et al., 2001). Fiction, depending on its viewpoint, aligns itself with certain articulated and unarticulated practices and values (Ferro, 1993), which reflect a reconstructed world view. It is this ability to reinvent reality (rather than simply duplicate it) that enables the filmic object to become part of the development of social processes and influence, to a greater or lesser extent, the opinions and behaviour of the general public (Delage et al., 2004).

This approach requires a comparison of what is learned from the filmic analysis with its external sources. The first focuses on the description and interpretation of the fictional narrative and its audiovisual dimension, in which the analyst must remember that cinema is a collective art. In this context, the question of exactly who is the author of a film has given rise to an abundant literature, which shows that it is not the director alone. On the contrary, the film's author is considered as a "virtual meeting room" a "speaker" or the "subject of the filmic narrative" (Aumont et al., 2002: 13-14).

The cinema is also an industry, subject to economic and cultural considerations that affect production. A filmic analysis alone is therefore insufficient and must be supplemented by an external analysis that integrates the work into its production context. It is only with this condition in mind that the researcher can succeed in identifying the anchor points that connect the work of fiction to its place in social space-time.

The film is therefore defined as an object that is inseparable from the society that produces and watches it. Researchers can approach their work by focusing on significant sequences, or establish sets of themes. This choice not only depends on the research question; it is also determined by how the film itself is composed.

\subsection{The monographic analysis}

The corpus of films concerning the nuclear industry corpus consists of two sets. The first includes works of fiction where the part of the action takes place in a power station (The China Syndrome, Grand Central). The installation forms part of the scenery; work situations are recreated and the balance of power between the operator and workers is explored. The second set includes films that address the issue of nuclear power but do not take place inside a plant, which may be confined to the background (Mount Fuji in Red, Land of Oblivion, The Land of Hope). The operational and organizational dimension is neglected in favour of a description of the consequences of a nuclear disaster on man and the environment.

A study of the themes that are explored in these two sets makes it possible to put into perspective the representations they convey - the interior of the installation, the operator, the nuclear risk, etc. However this poses a significant problem for researchers: the corpus, at a national level, is insufficient to carry out an analysis. Given this situation, a thematic study must compare films from different countries and different eras. For example, it would lead to a comparison of an American film from 1979 (The China Syndrome) and a French film from 2013 (Grand Central). Under these conditions, it becomes difficult to contextualize representations, as they refer to different cultural objects.

On the other hand, the monograph invites the researcher to focus their efforts on a single film, which resolves contextual problems. Specifically, we chose Grand Central for two main reasons. It is the first French film to focus so closely on workers in the nuclear sector, and second, its narrative is clearly centred on the relationship between the operator and subcontractors, which feeds the public debate on the sector. This work of fiction occupies an important place in the history of representations of the nuclear industry and clearly merits further analysis.

\subsection{Internal and external analysis}

For the internal analysis, the film must be considered from various angles, which correspond to the decomposition of its content. An internal analysis "does not consider the object (the film) in 
its entirety, but seeks to identify the various constituent components in order to identify organizational systems" (Journot, 2002: 6). The analysis begins by identifying the central plot themes, before dividing the film into sequences and describing the imagery and the soundtrack. The film cannot be studied in the same way as a novel as there are technical considerations which the analyst must identify and interpret. The objective is to formulate an explanation of the film, in other words to arrive at "an understanding of some of its raisons d'être" (Aumont et al., 2002: 6).

A sequence is a "series of scenes (or single scenes) that make up an individual or distinct piece of dramatic action" (Pinel, 2005: 365). Grand Central can be divided into 131 sequences. Most of them are diurnal (89) and filmed indoors (78). Our analysis is focused on sequences that address the nuclear industry (69). They concern segments where the work is mentioned but the installation does not appear onscreen, segments where the exterior of the plant is shown, and those where the action takes place in the facility. This brief description immediately highlights the importance of the relationship between the worker and the physical space in the film's narrative.

The external analysis takes a different point of view and focuses on the inspiration for the film in terms of writing and filming - as well as sources generated by the film. The press pack provides valuable information about the project's genealogy, the documentation used in writing the script, shooting locations, the role of technicians, etc. However, as this is a communication tool used to promote the work the information it contains must be used with caution.

An evaluation of the film's reviews indicates how well it was received on theatrical release. One critical review describes the work as not only meeting "certain aesthetic criteria" (Journot, 2002: 30 ), but also as a system of representations around which a social consensus is formed. Consequently, this critique reveals certain connections between the film and public opinion and the ideas conveyed on the topic.

These connections are fed by multiple types of media. With respect to Grand Central, the postFukushima environment increased television and radio reporting of subcontracting. Similarly, newspaper articles addressed the issue of workers in the nuclear sector. An examination of these sources therefore serves, on the one hand, to contextualise the film, and on the other to determine how it fits into public debate on the sector.

These methodological details highlight the difficulty of linking internal and external analyses. Academic research can quickly lead to an overly mechanical cultural interpretation. In order to avoid this pitfall, external influences at the time when the sequences were filmed must be taken into account. The contextual analysis should not be seen as an alternative to the filmic analysis, but rather its endpoint.

The approach rests on a delicate balance between the two forms of analysis, which mean that the film is sufficiently contextualized but the key elements that are essential in order to understand it are not lost (Marie, 1992). Researchers are therefore limited to a form of internal-external compromise, and must be careful to avoid overly rigid causal links as "any hypotheses that are derived from a text remain hypothetical" (Jullier, 2013: 160). This suggestion is particularly applicable to the study of Grand Central, due to the complex relationships that link it to the debate on nuclear power.

\section{THE IMAGE OF NUCLEAR POWER IN GRAND CENTRAL}

This second section uses the methodology described above to examine how nuclear power is represented in Grand Central. First, it outlines the inspiration for the film, before showing how the plant, the work and subcontractors are presented.

\subsection{The film's inspiration}

The film's director Rebecca Zlotowski said in an interview that the concept for the film came from her co-writer Gaëlle Macé, who had read La Centrale (Filhol, 2010), which is a novel about subcontractors in the nuclear industry. Zlotowski became interested in a story that she considered to have "significant documentary rigour" and that was about "a completely fictional community". A former subcontractor and author of an essay on decontamination work (Debout, 2010) was hired as an adviser and participated at all stages of the making of the film. These details, extracted from the press pack, lend credit to the film and had a certain influence on its critical reception.

The director states she did not conceive of Grand Central as either pro- or anti-nuclear, "My film is political, it is not militant. (...) The description that I present leads to an observation and this observation may lead to further thought. But in no case was this critical reflection the inspiration for the story. (...) To describe this world, this marginalised community of social outcasts, who can be sacrificed, is a political process" (Nouchi, 2013). Although the argument is legitimate, the distinction between "politics" and "militancy" remains unclear. Zlotowski's attempt to clarify the question only emphasizes the ambiguity. The Fukushima accident, which occurred during the writing of the screenplay, had a determinant impact on the authors, "Dozens of articles were published in the press documenting the daily lives of nuclear workers who were sacrificed there, as in France, and this tragic coincidence made 
us sure that there was a good reason to write the script" (Press pack, 2013). The director therefore creates a link between the working conditions of subcontractors and nuclear disaster. However, this link is often repeated in the public debate to question the safety of facilities, and can become an argument in favour of a potential withdrawal from nuclear power. If Grand Central's narrative is seen in the same vein as antinuclear activism, the film becomes very much a "political" object, although not in the sense that the director intended. The film's purported neutrality in the debate does not seem to hold true. The sequence analysis, in turn, tends to confirm this premise.

\subsection{The nuclear sector in images}

The representation of workers situates them in an imaginary space where the facility resembles a sacred place. Its cooling towers add to the aesthetic qualities and make us think of the bell towers of a cathedral, containing a mysterious power. They appear repeatedly, either in the background as visual elements of the landscape or as inserts, where they dominate the scene. These images represent the "nuclear brand", as the narrator says in the novel (Filhol, 2010: 25). The sacredness of the plant is again suggested when the main character first discovers the Cruas facility. The scene is shot from inside the plant. The door opens and the team leader enters first. He is followed by the others, while the door rumbles closed, as if the characters were entering an inner sanctum. The locker room is like a sacristy, where subcontractors get changed before entering the reactor to commune with the atom. The blue light emanating from the reactor's "choir" clearly represents the symbolism of this space where the profane are not allowed to enter - only the most experienced subcontractor is allowed to approach it. The sacred note, which is reflected in both the architecture and work processes (Bergé, 2010), therefore finds its place in the collective imagination related to the history of nuclear energy, which emerged from the development of the first French nuclear power centres (Hecht, 2004).

Subcontractors are proud to work in the sector. They value their profession, which requires motivation, concentration and a high level of precision. The team leader explains that the work is demanding, "If you do it, you do it well. You must be good, you must be capable". The film therefore portrays the characters as unsung heroes who are working for the public good. One of them makes it clear, "We bring light to the people!"

The industry's profit imperatives severely test worker's motivation and tend to the dehumanization of the job. A rapid recruitment process, a few days of training in radioprotection and a routine medical visit are the main character's introduction to the world of subcontracting. These steps are treated as mere formalities, and hiring procedures are immediately discredited. This representation also features in the novel, which compares the training of subcontractors to the training of young recruits in the Great War, "I was the one that trained the back of the front, lectures on theory, then ten days practice in the school yard, ten days made eight at the height of the offensive when we accelerated the training of recruits so that they were available as quickly as possible - after all, what was the point of investing any more time and money in people we knew would have a short career?" (Filhol, 2010: 18).

The film therefore treats the work of subcontractors as a struggle against radiation exposure. Their interventions are compared to a battle with a "colourless, odourless, invisible" enemy. In one sequence, workers wait in silence for the moment when they can enter the red zone. The team leader gives the signal and puts on his mask, quickly followed by the others. Time is suspended and the subcontractors seem to be preparing to mount an assault, as if in a war film.

Animal metaphors express the real danger of this confrontation. The protagonist rides a mechanical bull; in the same way workers try to tame the atom. The crocodile, seen during a visit to the zoo is as devious as radiation. It can sit still for hours in order to improve its chances of surprising its prey.

The films imagery highlights the solidarity between men who must face the risk of contamination. The team leader encourages the social relationships based on the value of sharing. He severely chastises the main character when he drinks all the water in the communal bottle. The team leader takes collective and equal responsibility for any mistakes, "Here it is nobody's fault, it's everyone's fault!" Subcontractors feel that they belong to the same world, which is characterized by working and living conditions that seem to come from a bygone era. This class consciousness was highlighted by Grand Central's technical advisor, who thinks that subcontractors are part of a large family, "They find themselves living in the same places: camping sites, hostels. They share the same worries about lack of security, separation from their families, the same risks, the same doubts, which brings them even closer together" (Press pack, 2013). In effect, the characters live in their own world, on the outskirts of the plant in cramped and uncomfortable mobile homes. Promiscuity cannot be avoided and the community likes to gather in the evening or for picnics in the countryside.

These very tight social relationships help the nuclear sector lumpenproletariat to endure the 
operator's domination. The film represents the relationship between the workers and the organization in a particularly distinctive dialectic: one car park is reserved for the "aristocrats" (employees of the operator) and another is for the "galley slaves" (the subcontractors). The team leader stipulates the privileges granted to the most important workers: lower exposure to radiation, better wages, a coffee machine, free electricity. The camera follows the characters as they leave the plant and head to their cars. The car park for the operator's employees remains off-screen, as if it is a place that is off-limits to subcontractors.

Domination is also takes the form of a sequence about decontamination. A female subcontractor is shot from behind, standing naked. Her face is not shown, which emphasises the anonymous nature of the operation, and she is cleaned with a water jet, which immediately suggests a prison environment. Radiation detectors indicate that young woman's hair is contaminated. She turns her head twice towards the radiation protection officers that stand round her. They decide to shave her head. Handfuls of hair are shown falling onto her legs. A close-up then shows the character's face; she is crying. The officer, who is partially out of the shot, carelessly shaves the woman's head. The physical assault evokes the idea of the concentration camp and the depersonalisation of workers.

A reduction in long-term outages increases not only tensions between the subcontractors, but also the accident rate. An intervention goes wrong and the main character is contaminated. During the medical examination, the doctor tells him that he must now work in the green zone. If he receives further exposure to radiation he will either be made unemployed for technical reasons, or sent to another site. The subcontractor refuses to accept the second option. The sequence continues silently as follows: the protagonist goes to the green zone and puts on his helmet. He then appears in the locker room, checking his dosimeter. The doctor (off camera) announces that he is now "suspended". In the film the operator is shown to fail to take responsibility for the health risks that the worker is exposed to and gets rid of him as soon as he becomes useless. The following sequence alternates between the young man and his lover, each in their respective locker rooms. The subcontractor asks, "What if I want to stay?" He does not receive any response. This decision on the part of the director lends a particular meaning to the sequence. The character approaches a stack of cylinders and hides his dosimeter, before recovering it at the end of the day. Consequently, the doctor's failure to answer can be interpreted as an incentive to circumvent regulations and behave irresponsibly, in contravention of any professional ethics.

The film therefore emphasizes the precarious situation of the subcontractor and the master-servant relationship between him and the operator. The latter takes advantage of the worker's lack of qualifications, deliberately puts his health at risk and does not acknowledge his contribution in any way. The characters' working and living conditions lead to individual and collective dramas: one worker becomes sterile, the team leader separates from his wife and no longer sees his children, some are contaminated, while the group gradually disintegrates. This representation of workers demonstrates the challenges of the debate on subcontracting, which itself is a controversy that is intrinsically linked to the development of nuclear technology (Boudia, 2007).

\section{THE ROLE OF CINEMA IN PUBLIC DEBATE ON NUCLEAR POWER}

This final section discusses how the narrative of Grand Central fits into public debate on the sector. An analysis of its critical reviews makes it possible to determine, aside from its aesthetic value, how credible the representation of nuclear power is. The reaction of the press, as much as the film itself, forms part of a broader network of representations of civilian nuclear power. Consequently, it appears to be difficult to challenge the narrative of Grand Central, as it seems off-limits for sociological, scientific and moral reasons. Nevertheless, there are other ways to view subcontractors and their relationships with operators.

\subsection{The critical reception of Grand Central}

The film received many positive reviews, both in the press and in specialised journals. These highlighted its intelligence and realism (Mandelbaum, 2103), its coherent aesthetic choices (Narbonne, 2013), the script's rigor (Ferenczi, 2013) and the actors' talent (Raspiengeas, 2013). There were only a few unfavourable reviews, which focussed on the schematic plot, and suggested that the film was a half-incarnated "world of ideas" (Ferenczi \& Strauss, 2013; Gester, 2013). While the harshest critics judged the narrative to be unconvincing, none questioned the way the industry was represented.

The plant is associated with several levels of symbolism. It is compared with a "nuclear hell" (Sotinel, 2013; Narbonne, 2013), an "evil stomach" or a "toxic bath" (Kaganski, 2013) in which workers are immersed. The reactors are seen as "modern mines" (Le Parisien, 2013) and the atmosphere of the facility is described as "prisonlike" (Delcroix, 
2013). Such terminology dramatizes the workspace, which becomes a place of suffering and alienation for workers who are "dogsbodies" (Ferenczi, 2013).

The precarious situation of the characters caught the critics attention, who used very strong language. Subcontractors were described as outcasts, the underclass, the walking dead. They are a shadow proletariat, a small tribe of untouchables who live in a world without hope. Workers are represented as convicts, "In their own way, they spend their time breaking stones waiting for their release from prison. They wear their dosimonitors like chains, to calculate their degree of irradiation" (Delcroix, 2013). The representation of nuclear sector workers is said to be all the more fascinating as it is far removed from "the neat official image of engineers and highly qualified technicians that is so often conveyed" (Lacomme, 2013).

As one, critics noted the documentary nature of the film. The scenes showing the apprenticeship seem "larger than life" (Ferenzi, 2103). The narrative "places each protagonist and situation in a specific professional context, indicative of current socio-economic reality" (De Bruyn, 2013). This almost documentary-like immersion demonstrates to the pubic "the reality" of workers in the nuclear sector (Bernheim, 2013).

These analyses are interesting for several reasons. First they make it possible to identify the points where the fictional story corresponds to other representations of nuclear power. Comments about the film find similarities with the pessimism of Emile Zola's novel Germinal, to describe a new form of servitude through work.

Moreover, by giving the film documentary value, critics crystallize representations on the precarious nature of subcontracting in the nuclear power sector.

\subsection{Contextualization of the film in the public debate}

The debate on nuclear energy concerns questions about its impact on public health and the environment, lack of transparency and democratic dialogue, the safety of installations, the risk of proliferation, waste management, profitability and the cost of dismantling (Barré et al., 2013). The Fukushima accident revived media interest in safety issues in France, which was closely linked to the debate on subcontracting. The real nature of the power relationships between operating companies and subcontractors are understood by researchers (Thébaud-Mony, 2000). Furthermore, the idea of the subordinate subcontractor is not specific to the nuclear sector, and authors have examined the risks of subcontracting in other sectors (Mayhew \& Quinlan, 1997).

The reasons for the use of subcontractors are at the heart of the controversy and are frequently cited by the media. The most common argument is without doubt the profitability imperative, which forces the operator to limit the duration of power outages and to use a cascade of subcontractors (Fayner, 2012). The outsourcing of health risks is a secondary argument: the health of workers is not given much weight and they are not under medical supervision, while the nuclear lobby refuses to recognize occupational cancers linked to ionizing radiation (Nicolas, 2013).

Another problem is the transmission of knowledge. This knowledge is lost as workers retire and subcontractors must train themselves on the job. The loss of continuity increases the potential for an accident, as "nothing can replace the memory and experience of workers who knew the installation" (Thébaud-Mony in Pascariello, 2011).

Finally, the acceleration in the pace of work due to the optimization of long-term outages (Gérard, 2011), increased levels of stress, the arduous nature of the work (Weiler, 2010) and loss of skills (Auffray, 2011) are seen as factors that threaten the safety of the facility and personnel. The narrative of Grand Central is consistent with this system of representations. Consequently, the film reflects the popular image of the sector presented in the media, which leaves little room for an alternative narrative.

\subsection{Factors that discourage discussion}

The visible part of a society consists of both the images producers broadcast and what audiences expect to see (Sorlin, 1977). In the context of our analysis, the subcontractor is only observed (and observable) in terms of insecurity and danger. Why is it therefore so difficult to develop an alternative representation and to criticize the film's medium? First, we must reformulate how modern society thinks about subcontracting. The transition to modernity is defined by a loss of confidence in technology and expertise. This discredit leads the population to feel vulnerable, a sentiment that is amplified by the globalization of risks and the hypermediatisation of technological accidents. Consequently, the idea that science enables social progress has been called into question since the mid1960s. It was in this context that civilian nuclear power became uncoupled from the idea of progress (Topçu, 2006). Since then, its detractors have associated it with counter-productivity at all levels. The nuclear disasters at Three Mile Island, Chernobyl and Fukushima crystallized this representation in the media, which structures the dissemination of information and influences civil society. However, this is only possible so long as the media makes clear its independence from the official line. This configuration of the public space, where 
the idea of a "nucleocracy" (a term coined to describe a mode of techno-political governance that combines various actors and pressure groups) has naturally tended to discredit arguments about power. Therefore, the media is obliged to criticise the nuclear sector in order to demonstrate its independence and usefulness.

The issue of subcontracting also highlights a problem linked to the accessibility of sources. The subject has received little attention from academics because of security issues related to nuclear energy and a lack of interest from social scientists in bluecollar workers. "In these conditions where it is difficult to access the situation on the ground, it is not surprising that journalists' treatment of the nuclear industry is confined to current concerns in all forms of televised news" (Fournier, 2012). This situation clearly limits the diversity of viewpoints.

One last factor explains the difficulty of criticizing the image of the subcontractor presented in Grand Central. The link that is made between work and social distress is what could be termed an "untouchable" representation. Developed societies are uncomfortable when faced with poverty, which is approached with great caution by the media. Calling into question the film's narrative could therefore be seen as an unacceptable attempt to justify the exploitation of the weak by the strong.

However, there are other potential representations that do not diminish the dignity of workers in the nuclear sector. In fact, the subcontractors depicted in Grand Central do not seem to be representative of this type of worker. While the film's bias helps to nourish the image of nuclear power in the popular imagination, it does not acknowledge the professionalism of subcontractors. It is clear that there is a part of the labour force in the nuclear sector that leads a precarious existence, and questions can be asked about why operators find it necessary to subcontract $80 \%$ of maintenance activities. However, the debate cannot be simply reduced to calling 20,000 subcontractors nomadic workers who are overexposed to radiation for the sake of economic efficiency. Subcontracting activities are many and varied, and while the lives of some workers are made precarious due to the nature of the contracts between operators and subcontracting companies (the social conflicts experienced by plants are witness to this), a large majority of subcontractors are employed in stable, long-term contracts.

The film does not mention the role of trade unions in the organization of nuclear industry workers. On the one hand, many workers are confident of their abilities and their professional identity, while on the other hand the distinction between employees of the operator and subcontractors is not entirely clear. Proof of this fact is found in real life, in the joint unionisation of the employees of the operator and subcontractors at the Cruas plant - precisely where the film's action is supposed to have taken place. Teams work together and the operator's employees are highly dependent on the skills of subcontractors. For example during delicate and complex cleaning and dismantling operations, contractors are clearly the experts and owners of the know-how. Such situations provide a less schematic image of subcontracting and open up perspectives that are more in line with the reality on the ground.

\section{CONCLUSION}

The presentation of the nuclear sector in Grand Central has attracted the attention of social scientists. The views presented in the film are indicative of current challenges in the public debate. They translate, starting with the description of subcontractors, concerns about working conditions in the sector and the security of French nuclear power plants. It is clearly essential, in the context of the post-Fukushima public debate, to examine the daily lives of subcontractors and once again question the human cost of energy. In this respect, Zlotowski's film contributes to the debate and provides a skilful look at aspects of the sector that are unknown to the general public.

In contrast, the relations between subcontractors and operators must also be analysed (and consequently be represented) in terms of joint operations. Interactions between subcontractors and operators are not based on simple dependency relations, but on strategies that lead to alliances (Martin et al., 2012). This shows that it is necessary to investigate, rethink and eventually make visible the entire set of power struggles and relationships.

\section{REFERENCES}

Auffray, E. 21 March 2011. Dans les centrales françaises, le malaise de la viande à radiations. In Libération.

Aumont, M. \& Marie, M. Dictionnaire théorique et critique du cinéma. Paris: Nathan.

Barré, B. \& Majnoni d'Intignano, S. 2013. Faut-il renoncer au nucléaire? Paris: Le Muscadier.

Bergé, C. 2010. Superphenix, déconstruction d'un mythe. Paris: La Découverte.

Bernheim, C. 21 August 2013. Nos coups de coeur de la semaine : Grand Central et Magic Magic. In Femme actuelle.

Boudia, S. 2007. Naissance et rebonds d'une controverse scientifique : les dangers de la radioactivité pendant la guerre froide. In Mil neuf cent, 25: 157-170. 
De Bruyn, O. 28 August 2013. Grand Central : Rebecca Zlotowski secoue nerveusement le ciné français. In Le Nouvel Observateur.

Debout, C. 2010. Je suis décontamineur dans le nucléaire, Editions Paul Ramand.

Delage, C. \& Guigueno, V. 2004. L'historien et le film. Paris: Gallimard.

Delcroix, O. 28 August 2013. Grand Central. In Le Figaro.

Fayner, E. 9 May 2012. Nucléaire : la bombe humaine. France 5.

Ferenczi, A. 19 May 2013. Grand Central ou la fission dangereuse du sentiment. In Télérama.

Ferenczi, A. \& Strauss, F. 28 August 2013. Grand Central. In Télérama.

Ferro, M. 1993. Cinéma et Histoire. Paris: Gallimard.

Filhol, E. 2010. La Centrale. Paris: POL Editeur.

Fournier, P. 2012. Travailler dans le nucléaire. Paris: A. Colin.

Gérard, M. 26 April 2011. A Dampierre, avec les nomades du nucléaire. In Le Monde.

Gester, J. 19 May 2013. Rebecca Zlotowski, centrale atomique. In Libération.

Grand Central. 28 August 2013. In Le Parisien.

Hecht, G. 2004. Le rayonnement de la France. Paris: Editions de La Découverte.

Incerti, M. 2013. Press pack. Ad Vitam.

Journot, M.-T. 2002. Le vocabulaire du cinéma. Paris: Nathan.

Jullier, L. 2013. L'analyse de séquences. Paris: A. Colin.

Kaganski, S. 27 August 2013. Très belle histoire de coeur et de réacteurs. In Les Inrocks.

Lacomme, J.-P. 24 August 2013. Sous hot tension. Le Journal du Dimanche.

Mannoni, P. 1998. Les représentations sociales. Paris: PUF.

Mandelbaum, J. 26 August 2013. Grand Central : une folle chamade sur fond de radioactivité. In Le Monde.

Marie, M. 1992. Texte et contexte historique en analyse de films. In Cinémaction, $\mathrm{n}^{\circ}$ 65: 22-28.

Martin, C. Portelli, A Guarnieri, F. 2013. Myths and Representations in French Nuclear History. 22nd ESREL Conference - Safety, Reliability and Risk Analysis, Amsterdam.

Martin, C. \& Guarnieri, F. 2012. Nuclear decommissioning and organizational reliability, involving subcontractors in collective action . In SFEN.

Mayhew, C. \& Quinlan, M. 1997. The management of health and safety where sub-contractors are employed. Journal of Occupational Health and Safety, Australia.

Nicolas, B. 21 May 2013. Centrales nucléaires: démantèlement impossible? Arte.

Narbonne, C. August 2013. Grand Central. In Première.

Nouchi, F. 26 August 2013. Rebecca Zlotowski : Mon film est politique, il n'est pas militant. In Le Monde.
Pascariello, P. 28 October 2011. La sous-traitance dans le nucléaire. France Inter.

Pinel, V. 2005. Vocabulaire technique du cinéma. Paris: A. Colin

Puiseux, H. 1987. L'apocalypse nucléaire et son cinéma. Paris: Les Editions du Cerf.

Raspiengeas, J.-C. 19 May 2013. Le Démantèlement et Grand Central. In La Croix.

Sorlin, P. 1977. Sociologie du cinéma. Paris: A. Montaigne.

Sotinel, T. 20 May 2013. Grand Central: fission amoureuse à l'ombre de la centrale. In Le Monde.

Thébaud-Mony, A. 2000. Sous-traitance et servitude. Paris: Inserm.

Topçu, S. 2006. Nucléaire : de l'engagement savant aux contreexpertises associatives. In Natures Science Sociétés: 249266.

Vanoye, F. et al. 2001. Précis d'analyse filmique. Paris: Nathan.

Weiler, N. 11 October 2010. Les droits bafoués des soustraitants du nucléaire. In Bastamag. 